\title{
Taxes and Civil Rights: "Constitutionalizing" the Internal Revenue Code
}

\author{
Boris I. Bittker* and Kenneth M. Kaufman†
}

In McGlotten $v$. Connally, a three-judge federal court held that the Secretary of the Treasury could not grant federal income tax exemptions to fraternal orders that exclude nonwhites from membership or allow gifts supporting the charitable functions of such organizations to be deducted by the donors as charitable contributions in computing taxable income. ${ }^{1}$ In the court's view, these tax benefits constitute federal "subsidies" that, if granted to a fraternal order with a racially restrictive membership policy, would violate the Due Process Clause of the Fifth Amendment as well as the statutory prohibition on discrimination in "any program or activity receiving Federal financial assistance" imposed by Section 601 of the Civil Rights Act of 1964." The court also held that "a clearly indicated Congressional policy" against racial discrimination by "the beneficiaries of federal largesse" required that the Internal Revenue Code be construed to disallow a deduction for contributions to fraternal orders excluding nonwhites from membership. ${ }^{3}$ Although the plaintiff also attacked the income tax exemption of segregated nonprofit social clubs, the court held their exemption to be more limited than the tax benefits enjoyed by fraternal orders, and therefore not burdened with the same prohibition on racial discrimination. ${ }^{4}$

The plaintiff, a black American allegedly denied membership in an Oregon lodge of the Benevolent and Protective Order of Elks solely because of his race, did not ask for a judicial order directing the Elks to admit him to membership or to abandon their policy of admitting only "white male citizens of the United States"; nor did he confine his attack to the tax benefits that might be claimed by this one fraternal order. His objective, rather, was to deny federal tax benefits to all dis-

* Sterling Professor of Law, Yale University.

$\dagger$ A.B. Harvard University, 1969; J.D. Yale University, 1972.

1. 338 F. Supp. 448 (D.D.C. 1972); see also Pitts v. Wisconsin Dept. of Revenue, 333 F. Supp. 662 (E.D. Wisc. 1971) (enjoining state grant of property and income tax exemption to clubs, societies, fraternal orders, and other associations with racially restrictive membership rules as violating Fourteenth Amendment).

2. 42 U.S.C. $\$ 2000$ (d) (1970).

3. 338 F. Supp. at 460 .

4. Id. 
criminating fraternal orders and social clubs. The court upheld the plaintiff's standing to raise the discrimination issue in this novel fashion, and ruled that his action was not barred by the Tax Injunction Act (prohibiting injunctions against the assessment or collection of taxes) ${ }^{5}$ or by the Declaratory Judgment Act (prohibiting declaratory judgments "with respect to Federal taxes"). ${ }^{6}$

McGlotten v. Connally breaks important new ground in four areasthe jurisdictional and standing requirements for suits challenging someone else's tax status; constitutional restrictions on federal tax benefits; the role of "public policy" in construing Internal Revenue Code provisions conferring tax benefits; and the scope of the term "program or activity receiving Federal financial assistance" in Section 601 of the Civil Rights Act of 1964. The procedural aspects of the case have major implications for the maintenance of suits by "public interest" litigants. ${ }^{7}$ The main constitutional issue at stake-the scope of "state action"-has been largely dormant since Burton $\%$. Wilming. ton Parking Authority ${ }^{8}$ because statutory remedies for racial discrimination have largely replaced constitutional ones. ${ }^{0}$ McGlotten also has

5. INT. Rev. CODE § 7421(a).

6. 28 U.S.C. $\S 2201$ (1970). The court did not discuss the possibility that the suit might have been regarded, in view of its purpose, as an action "for the collection or recovery of taxes," barred by $\$ 7401$ of the Internal Revenue Code unless the Treastury and Justice Departments authorize it.

7. In 1971, Ralph Nader's Public Interest Research Group sued to enjoin the Treasury Department from issuing proposed Asset Depreciation Range regulations without a hearing under the Administrative Procedure Act. The suit was withdrawn when the Treasury announced that hearings would be held. N.Y. Times, Jan. 26, 1971, at 16, col. 4. After the regulations were issued, Common Cause and a group of other plaintiffs sued for a declaratory judgment that the regulations were invalid and for an injunction compelling their withdrawal, primarily on the ground that they were beyond the Treas. ury's authority under the Internal Revenue Code. Civil No. CA 1397-71, D.D.C. See Bittker, Treasury Authority to Issue the Proposed "Asset Depreciation Range System" Regulations, 49 TAxes 265 (1971). This suit was dismissed when Congress amended the Code to authorize a similar depreciation system. $\$ \$ 167(\mathrm{~m})$ and $263(\mathrm{f})$, cnacted in 1971 .

See also Report of Special Committee [of $A B A$ Tax Section] on Standing to Sue, 25 TAX LAwYER 631 (1972); Louisiana v. MCAdoo, 234 U.S. 627 (1914) (State of Loulsialla cannot compel Treasury to collect higher duties on sugar than Treasury belicved were due); Wolkstein v. Port of New York Authority, 178 F. Supp. 209 (D.N.J. 1959) (taxpayer cannot compel Treasury to assess income tax against holders of bonds issticd by Port of New York Authority); Panel Discussion, Standing to Ste, 26 TAX LAwYEk 27 (1972).

8. 365 U.S. 715 (1961).

9. But see Moose Lodge No. 107 v. Irvis, 407 U.S. 163 (1972), holding that a Moose Lodge could retain a state liquor license despite its racially restrictive membership rules. By describing the lodge in this case as "not publicly funded" (despite the fact that it no doubt enjoyed the same tax exemption as the fraternal order in Mcclotlen) and stating that "while [the restaurant in Wilmington Parking Authority] was a public restaurant in a public building, Moose Lodge is a private social club in a private building," 407 U.S. at 175, this decision may at first blush be thought to overrule McGlotten, albeit implicitly. But the sole issue raised by the Moose Lodge plaintiff was that the lodge's state liquor license met the "state action" criteria of Wilmington Parking Authority. Under these circumstances, the lodge's tax exemption can be properly regarded as a question that merely "lurked in the record," and that was not decided by the Court. 
important implications for statutory interpretation, both in its novel (though not unprecedented) reading of the Internal Revenue Code and in its broad construction of the language of the 1964 Civil Rights Act.

\section{Litigation Challenging a Third Party's Tax Status}

In challenging the tax exemption of segregrated fraternal orders and social clubs and the right of donors to deduct contributions to segregated fraternal orders, the plaintiff in McGlotlen had to establish his standing to raise these issues. He also had to escape the statutory limitations imposed on tax litigation by the Tax Injunction Act and the Declaratory Judgment Act.

\section{A. Standing}

The standard used by the court in testing the plaintiff's standing to sue was the two-part test set out by the Supreme Court in $A s s^{\prime} n$ of Data Processing Service Organizations v. Camp: ${ }^{10}$

(1) For purposes of the "case or controversy" requirement of Article III of the Constitution it must appear "that the challenged action has caused injury in fact, economic or otherwise"; and (2) as a matter of judicial self-restraint, the court must determine "whether the interest sought to be protected by the complainant is arguably within the zone of interests to be protected or regulated by the statute or constitutional guarantee in question."11

The injuries alleged by the plaintiff, which were held by the court to be sufficient to establish his standing to sue, were:

First, that the funds generated by [the disputed federal] tax benefits enable segregated fraternal orders to maintain their racist membership policies; and second, that such benefits constitute an endorsement of blatantly discriminatory organizations by the Federal Government. ${ }^{12}$

While these injuries are especially palpable to a person who is actually excluded from membership in a fraternal order because of his race,

10. 397 U.S. 150 (1970); see also Siern Club v. Morton, 405 U.S. 727 (1972).

11. 338 F. Supp. at 452 , quoting 397 U.S. at $152-53$ [footnotes omitted].

12. $338 \mathrm{~F}$. Supp. at 452 . The plaintiff also alleged that he was injured beause his tax burden and that of the class he represented were increased by the fraternal order's tax allowances, but the court did not find it necessary to pass on this contention as a foundation of his standing to sue. 
they are surely also felt by blacks who have no interest in joining the order. This may have been why the court permitted the plaintiff to complain not only about the Elks, but also about the membership rules of all segregated fraternal orders and social clubs. In Moose Lodge No. 107 v. Irvis, however, the Supreme Court held that a Negro who had been refused service by a segregated fraternal order, when he entered its clubhouse as the invited guest of a member, did not have standing to litigate the constitutional. validity of the order's membership rules, since he had not sought membership. ${ }^{13}$ The Court's assertion that the plaintiff was seeking "redress for injuries done to others" assumes a constricted, and not wholly persuasive, definition of "injury," and it is worth exploring the consequences of the more liberal view of McGlotten.

In applying the First Amendment, the Supreme Court has distinguished between the Free Exercise Clause, which can be invoked only by a person whose right to worship has been infringed by the action complained of, and the Establishment Clause, which can be enforced by a broader circle of persons. ${ }^{14}$ Similarly, racial discrimination in violation of the Equal Protection Clause might be treated not simply as an affront to those who directly suffer from it, but as a public evil. Only ten days after deciding the Moose Lodge case, the Supreme Court held that the systematic exclusion of Negroes from jury service is so offensive to the Constitution that white defendants are as entitled as black defendants to demand a new trial before properly selected juries. ${ }^{15}$ The opinion suggests a variety of potential sources of unfairness to a white defendant in being tried before an all-white jury, but it is hard to avoid the conclusion that the defendant was allowed to act more as a private attorney general to redress a public wrong than as an aggrieved private appellant. A similar process of reasoning suggests that whites, who are frequently charged with "collective responsibility" for racism even though the practice is offensive to many of them, should have the same right as black citizens to sue to abate unlawful racial discrimination. If this extension of the holding in McGlotten $v$. Connally is accepted, the courthouse doors might be open to white members of a fraternal order who disagree with their organization's racially restrictive membership policies-and perhaps to any plaintiff, white or black, whether or not interested in joining

13. 407 U.S. at 168 .

14. McGowan v. Maryland, 366 U.S. 420, $429-31$ (1961).

15. Peters v. Kiff, 407 U.S. 493 (1972). 
the order, who is seriously affronted by the mere existence of racially restrictive policies.

Even with such an expansion of permissible plaintiffs to raise constitutional claims, however, MIcGlotten would not greatly facilitate tax litigation by "public interest" litigants, because valid constitutional objections to Treasury action are few and far between. ${ }^{10}$ More significant, for "public interest" litigation, is the court's theory that tax exemptions and deductions are the equivalent of "subsidies" and hence can be viewed as expenditures of public funds. This suggests that a public interest litigant who believes that a Treasury regulation or decision is legally defective in any respect, e.g., that it is not consistent with the Internal Revenue Code, can bring a taxpayer's suit ${ }^{17}$ alleging that the Treasury is making an unauthorized or impermissible "expenditure" of public funds. In McGlotten, the plaintiff asserted that he had standing to sue as a taxpayer; but having sustained his standing to sue on the ground set out above, the court did not reach this broader contention. It is unlikely, however, that the federal courts will have much taste for re-examining every Treasury regulation, ruling, or decision that a public-spirited citizen believes to be erroneously generous to his fellow taxpayers, even though he may have to pay part of the cost of repairing the fiscal damage. ${ }^{18}$ This probable judicial

16. Since the court upheld both the constitutional and statutory attacks on the fraternal order's tax benefits in McGlotten, it did not have to determine whether the plaintiff's standing would have been lost had he coupled an invalid constitutional objection with a valid statutory ground. If a valid statutory ground would have saved the complaint in these circumstances, the courts might as well entertain a case that alleges only a statutory ground; otherwise, the plaintiff would be impelled to conjure up a constitutional claim, however thin, just to establish his standing to obtain judicial resolution of his statutory claim.

17. See Flast v. Cohen, 392 U.S. 83 (1968); Davis, Standing: Taxpayers and Others, 35 U. ChI. L. REv. 601 (1968); Bittker, The Case of the Fictitious Taxpayer: The Federal Taxpayer's Suit Twenty Years After Flast $v$. Cohen, id. at 361 (1969); Davis, The Case of the Real Taxpayer: A Reply to Professor Billker, id, at 375; Jaffe, The Citizen as Litigant in Public Actions: The Non-Hohfeldian or Ideological Plaintiff, $110 \mathrm{U}$. PA. L. REv. 1033 (1968).

Further, if exempting an individual from tax is equivalent to subsidizing him, excluding an individual from an expenditure program should be viewed as equitalent to taxing him. This corollary, if accepted, would greatly enlarge the circle of potential plaintiffs in "taxpayer" suits.

18. In IBM v. United States, 343 F.2d 914 (Ct. Cl. 1965), cerl. denied, 382 U.S. 1028 (1966), the court allowed a business taxpayer to establish that its major competitor re. ceived a favorable tax ruling on a disputed issue of law, as a prelude to winning cqual treatment for itself under the Due Process Clause of the Fifth Amendment, even though the ruling was erroneous. (But cf. Farmers' and Mlerchants' Bank v. United States, \$il F. Supp. 929 (N.D. W. Va. 1972).) Whatever may be the fate of this pioneering appliation of the Due Process Clause to administrative procedure in the tax ficld, the basic value served by permitting taxpayers to benefit equally from administrative mistakes is equality among taxpayers, not protection of the revenue. The IBMI case, therefore, has no direct bearing on whether a citizen has a right to a judicial hearing if he thinks that the Treasury has misinterpreted or misapplied the Internal Revenue Code to the government's detriment, and seeks accordingly to compel the Treasury to collect taxes 
reluctance raises questions about the scope and practicality of McGlotten's "tax subsidy" theory, which will be examined in detail in Part II of this article.

\section{B. Statutory Barriers to Tax Litigation}

As stated earlier, in addition to establishing his standing to sue, the plaintiff in McGlotten had to surmount two statutory barriers to tax litigation-the Tax Injunction $\mathrm{Act}^{10}$ and the Declaratory Judgment Act. ${ }^{20}$ These provisions are best understood in context.

At common law, a tax assessment was akin to a judgment, creating an obligation to pay and a correlative right in the sovereign to collect the assessed amount by seizure of the taxpayer's goods. No matter how erroneous the assessment might be, the taxpayer's only remedy was to protest his liability and sue for a refund, and even this protection against unjustified exactions depended on a statutory waiver of sovereign immunity. The harsh regimen of pay-now-sue-later was relaxed for the federal taxpayer, however, by the creation of the United States Tax Court, which has general jurisdiction to decide before payment whether a proposed assessment of income, estate, or gift taxes is valid. The availability of this procedure grants the federal taxpayer who is threatened with an income, estate or gift tax assessment a choice between the traditional remedy of paying the disputed amount and then suing for a refund and the newer method of refusing to pay until liability has been established by litigation. In either case, however, the taxpayer has the burden of proving that the tax is not due.

from beneficiaries of the government's allegedly improper leniency. If the citizen at. tempts to analogize himself to the plaintiff in the $I B M$ case by alleging that he will have to pay higher taxes in the future unless the Treasury is compelled to move against the alleged delinquents, he may be told that his financial interest is too speculative and imperceptible to satisfy the requirement of "standing to sue." The premise underlying such a response would be that the Treasury is capable of protecting the fisc without a private watchdog or that, if aid from the citizenry is required, it will be solicited by the appropriate authorities. The Treasury is authorized by $\$ 7629$ of the Internal Revenue Code of 1954 to pay rewards to informers if their information proves to be useful; but informers tell their tales to the Treasury, not to the courts, and they cannot compel a reluctant Treasury to move against an allegedly delinquent taxpayer.

19. INT. REv. CODE $\$ 7421$ (a).

20. 28 U.S.C. $\$ 2201$ (1970). Another possible basis for denying juriscliction in the suit-the doctrine of sovereign immunity-was discussed by the court only in a footnote. 338 F. Supp. at 454 n.27. The court characterized the plaintiff's action as falling within the two exceptions to the doctrine outlined in Dugan v. Rank, 372 U.S. 609, 621.22 (1963)-that the plaintiff alleged "actions by officers beyond their statutory powers" (in claiming that the tax benefits are not authorized by the Internal Reventte Code and thit they violate the Civil Rights Act of 1964) and that "the powers themselves or the manner in which they are exercised are constitutionally void" (in claiming that the grant of tax benefits was unconstitutional). Id. 404 U.S. 997 (1971), mem. aff'g, Grcen v. Conl. nally, 330 F. Supp. 1150 (D.D.C. 197I). The court noted that Coit v. Grecn upheld similar injunctive relief against the same officials. 
Though the taxpayer is thus granted a choice of methods to challenge alleged tax deficiencies, attempts to employ other methods are restrained by two statutory prohibitions. Section 7421(a) of the Internal Revenue Code (the so-called Tax Injunction Act) provides that "no suit for the purpose of restraining the assessment or collection of any tax shall be maintained in any court by any person, whether or not such person is the person against whom such tax was assessed." This prohibition has been construed to have a draconic sweep, consistent with its uncompromisingly broad language. ${ }^{21}$ Lest it be sidestepped, the federal Declaratory Judgment Act excludes controversies "with respect to Federal taxes" from its own coverage. For the taxpayer who wishes to challenge a proposed tax assessment, then, Congress has prescribed the procedures to be followed and has forbidden the use of alternate routes.

But Congress has not given explicit statutory attention to the citizen who interests himself in someone else's tax liability. Since the plaintiff in $M I C$ Glotten sought an injunction to restrain the granting of tax benefits, he appeared to be outside the literal reach of $\$ 7421$ (a)'s prohibition on suits "for the purpose of restraining the assessment or collection of any tax." Holding that the central purpose of $\$ 7421$ (a) is to permit the government to assess and collect taxes promptly, without judicial intervention, the court found it "clearly inapplicable" to the plaintiff's action..$^{22}$ Another possible function of $\$ 7421(\mathrm{a})$, how-

21. In Enochs v. Williams Packing \& Navigation Co., 370 U.S. 1 (1962), for cxample, a corporate taxpayer alleged that it would be thrown into bankruptcy if the Internal Revenue Service were allowed to collect social security and unemplojment taxes that the taxpayer claimed were not owed. The Supreme Court refused to read an exception into Section 7421(a) for taxes whose collection "would cause an irreparable injury, such as the ruination of the taxpayer's enterprise." The only concession the Court was willing to acknowledge was a right, despite Section 7421(a), to enjoin collection "if it is clear that under no circumstances could the Government ultimately prevail." and even this dispensation was conditioned upon showing that the government's inability to win was apparent "on the basis of the information available to [the government] at the time of the suit," taking "the most liberal view of the law and the facts." Id. at 7 .

22. $398 \mathrm{~F}$. Supp. at 454 . The court went too far in saying that "[P] Iaintiff's action has nothing to do with the collection or assessment of taxes," id. at 453 [emplissis added], but it is true that he was in no sense secking to prevent taxes from being assessed or collected. The court pointed out that the preferred course of maintaining the action in the form of a suit for refund was not available to the plaintiff. $I d$.

Having held that $\$ 7421$ (a) leaves the door open to injunctions compelling taxes to be assessed and collected, the court did not have to deal directly with the fact that it prohibits suits not only by taxpayers, but by "any person, whether or not such person is the person against whom such tax was assessed." But the court explained in a footnote that this part of $\$ 7421$ (a) was enacted in 1966 "to deal with the narrow" problem of the third party who held a lien which competed with the tax lien held by the Gov: ernment," by requiring the third party to pursue a newly authorized remedy (suit under the Federal Tax Lien Act of 1966) instead of using an injunction against collection of taxes from the property over which he claimed a lien. Id. at 443, n.25. The court cridently read this history to mean that the 1966 amendment to $\$ 7421$ (a) was designed merely to curtail the rights of lien-holders, and not to apply to other persons. But the 
ever, is to minimize interference with the administrative process of assessing and collecting taxes, an objective that was partially undermined by the McGlotten decision.

Having held that $\S 7421$ (a) does not bar a lawsuit that has the effect of compelling, rather than restraining, the assessment and collection of taxes, the court turned to the Declaratory Judgment Act's exclusion of controversies "with respect to Federal taxes" from its coverage. The purpose of this restriction, according to the court, was merely to limit "the jurisdiction of the courts to issue declaratory judgments in the same fashion as their general jurisdiction was limited by the Tax Injunction Act [\$ 7421(a)]." Thus, the court concluded that the excep. tion in the Declaratory Judgment Act is "coterminous" with $\S 7421(a)$, and that "[i]f the injunctive relief requested by plaintiff is barred by the Tax Injunction Act, so too will relief be barred by the Declaratory Judgment Act." ${ }^{23}$ By reducing the Declaratory Judgment Act to a mere echo of $\$ 7421(\mathrm{a})$, however, the court deprives it of any independent significance. Statutory redundancy is not unknown, of course, but it is not to be presumed; and the fact that Congress amended the Declaratory Judgment Act in 1935 to exclude controversies "with respect to Federal taxes" argues for giving the amendment some independent significance. In his authoritative treatise on declaratory judgments, Professor Borchard argued that the 1935 amendment was more restrictive than the Tax Injunction Act, and recommended that its scope be reduced by amendment. ${ }^{24}$ Other courts, therefore, may disagree with the McGlotten conclusion that the 1935 amendment to the Declaratory Judgment Act is coterminous with $\S 7421(a)$, in which event that amendment may prove to be a formidable barrier to public interest litigation in the tax area.

"third party lien-holder" theory is not entirely persuasive, since it implies that such persons were free of the prohibition of $\$ 7421$ (a) before 1966. According to the Committee Report on the 1966 legislation, however, lienholders generally could not obtain review of their claims prior to 1966 :

Under present [i.e., pre-1966] law ... the United States cannot be sued by third

persons where its collection activities interfere with their property rights. This in.

cludes cases where the Government wrongfully levies on one person's property in

attempting to collect from a taxpayer. However, some courts allow suits to be

brought against district directors of Internal Revenue where this occurs.

H.R. REP. No. 1884, 89th Cong., 2d Sess. (1966), reprinted in 1966.2 CuM. Butu. 815, at 896. To remedy this situation, the Committee recommended enactment of $\$ 7426$, allowing "persons other than taxpayers" to bring suits against the United States to protect their liens on property levied upon by the Treasury. Having provided this remedy for third. party lienors, Congress amended $\S 7421$ (a) by adding specific language forbidding suits by non-taxpayers and by excepting the newly enacted $\$ 7426$ from its otherwise broad ambit. While the issue is debatable, the 1966 amendment might be construed to be more declaratory than innovative. So construed, it may restrict all third persons, not merely the third-party lien-holders mentioned by the court in McGlotten.

23. 338 F. Supp. at 453 .

24. E. Borchard, Declaratory Judgments 850.57 (2d ed. 1941). 


\section{Binding the Absent Parties}

A fraternal order that is denied a tax exemption by the Treasury pursuant to McGlotten may seek to relitigate the issues decided there, either by suing for a refund or by petitioning the Tax Court to expunge the proposed deficiency. If, in such a later suit, the fraternal order does not contest (or cannot successfully rebut) the charge of racial discrimination, is it nonetheless entitled to a de novo determination of the three legal issues decided by the McGlotten court-that the granting of a tax exemption would violate the Constitution and $\S 601$ of the Civil Rights Act of 1964 and would, moreover, not be authorized by the Internal Revenue Code? Not having been a party to the McGlotten suit, the fraternal order would not be bound by res adjudicata or collateral estoppel; at most, the original decision would constitute an adverse precedent. Indeed, it is arguable that the case should not even be regarded as an adverse precedent, since it was lost by a party (the government) that had more to gain by losing than by winning. Upholding the plaintiff's standing to sue, the McGlotten court said that his allegations of injury insured that the dispute to be adjudicated "will be presented in an adversary context," as required by Flast $v$. Cohen. The court did not, however, consider whether the government's financial interest in losing might stand in the way of an equally vigorous defense. (By analogy to the issue of whether the plaintiff had "standing to sue," one might ask whether the defendant had "standing to defend.") Conflicts among government agencies over the positions to be taken in federal litigation are not unfamiliar phenomena, and they may result in confessions of error or in waivers of particular defenses because to win on those grounds would conflict with positions taken in other lawsuits or proceedings. One need not imply that a government lawyer would camouflage a half-hearted defense with a pretense of vigor to suggest that a federal agency might be more selective and cautious than a no-holds-barred taxpayer in defending a tax exemption case with political overtones. When the Elks sought to intervene in McGlotten $v$. Connally, the plaintiff argued that the order's interest was "adequately represented by the government" so that there was no absolute right to intervene, and that permissive intervention should be denied because the motion was not timely filed. Although these objections were overruled and the Elks were allowed to intervene, there is no way to give formal notice to every affected party in an action like McGlotten, and it would be entirely possible for some of the numerous organizations affected by such a 
suit to lack even informal knowledge of its pendency. ${ }^{25}$ The courts may respond to these considerations by minimizing the precedential weight of the public interest litigation when the taxpayer who is directly affected relitigates the issues in subsequent proceedings. If so, the first lawsuit will in effect prevent the Treasury from voluntarily granting the disputed tax allowances, a result virtually insuring double litigation in most instances.

McGlotten v. Connally raises problems of "adequate representation" not only for taxpayers whose exemptions are challenged, but also for the class represented by the plaintiff-described by him as consisting of "all qualified non-white males who are excluded from membership in segregated fraternal organizations and clubs by reason of their race or color and ... all other persons paying taxes to the United States." The plaintiff did not ask for a judicial order compelling the Elks to admit him to membership-indeed, he did not even allege that he was willing to accept membership. Nor did he ask that the order be compelled to abandon its restrictive membership rules. His demand, rather, was that the order's tax allowances be denied.

Other members of the same class, however, might prefer an order compelling the Elks to admit members without regard to race. But if the Elks cling to their restrictive membership rule despite the loss of their tax allowances, an excluded Negro who wishes to gain entry after the decision in McGlotten $v$. Connally must face the fact that the order no longer enjoys the disputed tax benefits. Despite this fact, a court that wishes to give full sweep to the "subsidy" rationale might decide that a fraternal order that had enjoyed "subsidies" for many years is now so much a creature of public bounty that it must conform to the standards that apply to public agencies, even if it offers to "buy" freedom by renouncing future subsidies. ${ }^{26}$ The Girard College litigation suggests that a private organization with a long history of pub. lic support may not be allowed to cut the umbilical cord. ${ }^{27}$ But this is not the only possible answer to an excluded black who seeks admission to a segregated fraternal order after McGlotten. He might be told, even by a court that would have ordered his admission if he had sued

25. On intervention, see Cascade Natural Gas Corp. v. El Paso Natural Gas Co., 368 U.S. 129 (1967); Smuck v. Hobson, 408 F.2d 175 (D.C. Cir. 1969); D. Louisell \& G. Hazard, Cases and Matejials on Pleadinc and Procedure $731-35$ (2d ed. 1968).

26. Note also that the fraternal order has no way of compelling donors who have already made contributions to refrain from deducting them under $\$ 170(\mathrm{c})(4)$; this might lead a court to order a black admitted despite the fraternal order's preference for relinquishing its own tax exemption.

27. See Pennsylvania v. Brown, 260 F. Supp. 323 and 358 (E.D. Pa. 1966). 
before McGlotten was decided, that his only lever-the fraternal order's tax exemption-was obliterated by that decision. ${ }^{28}$

\section{Constitutionality of Tax Benefits Granted to Fraternal Orders and Social Clubs}

\section{A. Tax Allowances as "State Action"}

Turning from the procedural aspects of the McGlolten case to its constitutional issues, the court commented that the plaintiff's claim

leads us into the murky waters of the "state action" doctrine, for we must determine whether by granting tax benefits to private organizations which discriminate on the basis of race in membership, the Federal Government has supported or encouraged private discrimination so as to have itself violated plaintiff's right to the equal protection of the laws. ${ }^{29}$

The fountainhead of the "murky waters" which the MLGlotten court was required to navigate in making this determination was, of course, Burton v. Wilmington Parking Authority. ${ }^{30}$ In that case, the Supreme Court held that a private restaurant located in a building owned by a public agency, adjacent to a public garage, was required by the Equal Protection Clause to serve all comers regardless of race. But the Court warned that "the conclusions drawn from the facts and circumstances of this record are by no means declared as universal truths on the basis of which every state leasing agreement is to be tested," that it is impossible to announce "a precise formula for recognition of state responsibility under the Equal Protection Clause," and that each case requires a judicial process of "sifting facts and weighing circumstances." 31

The "facts and circumstances" which led the McGlotlen court to hold that discrimination by fraternal orders with racially restrictive

28. He would, of course, be able to assert any other grounds for concluding that the fraternal order came within the Wilmington Parking Authority doctrine. See, e.g., the reference in Moose Lodge No. 107 v. Irvis, 407 U.S. at 178, to Daniel v. Paul, 395 U.S. 298 (1969) (recreational facility masquerading as "private club"), and the reference in the Douglas-Marshall dissent in Moose Lodge No, 107, 407 U.S. at 180, to clubs that become centers of community activity, a position reminiscent of Terry $\checkmark$. Adams, 345 US. 461 (1953) (political club treated as intrinsic part of clection process).

29. 338 F. Supp. at 455 .

30. 365 U.S. 715 (1961).

31. Id. at 722 and 725 . 
membership rules is supported or encouraged by the Federal Government ${ }^{32}$ consisted of two provisions of the Internal Revenue Code: $\S 501(c)(8)$, exempting the fraternal order itself from federal income taxation, and $\S 170(c)(4)$, permitting contributions to fraternal orders to be deducted by the donor "if such contribution . . . is to be used exclusively for religious, charitable, scientific, literary, or educational purposes, or for the prevention of cruelty to children and animals." ${ }^{33}$ Holding that these "facts and circumstances" by themselves constituted federal support or encouragement, the court was able to apply its decision to all fraternal orders, without regard to the size of their membership or financial resources, the nature of their activities and facilities, or their other characteristics. A local all-black fraternal order composed of friends and neighbors is thus as much affected by $\mathrm{MC}$ Glotten as an all-white lodge located in a state capital with a membership that has a de facto monopoly of political influence.

Moreover, the "tax subsidy" rationale of the McGlotten case has implications beyond the area of racial restrictions. Since the restaurant before the Court in Wilmington Parking Authority would probably have been forbidden to impose restrictions based on its customers' religion, national or ethnic origin, political allegiance, sex, and perhaps other characteristics, McGlotten's logic apparently prohibits the granting of tax allowances to a fraternal order that imposes such restrictions on its memberships. Finally, nothing in McGlotten limits its reach to income, estate and gift taxes; "subsidies" in the form of exemptions, deductions, special rates, and similar allowances may be found in other federal taxes, as well as in state and local taxes. ${ }^{.34}$

The core of the constitutional holding in McGlotten is that the tax allowances granted by $\S 501(c)(8)$ to fraternal orders and by $\S 170(c)(4)$ to donors contributing to their charitable functions are "subsidies" rather than provisions serving "as a matter of pure tax policy" to define the scope of the term "income." Acknowledging, however, that "[e]very deduction in the tax laws provides a benefit to the class who may take advantage of it" and that its withdrawal "would often act as a substantial incentive" to alter the taxpayer's behavior, the court concluded

32. In relying on Wilmington Parking Authority, the court accepted the usual view that the Fifth Amendment imposes substantially the same obligations on the federal government, so far as racial restrictions are concerned, as the Equal Protection Clause of the Fourteenth Amendment imposes on the states. See Bolling v. Sharpe, 847 U.S. 407, 499 (1954) and Schneider v. Rusk, 377 U.S. 163, at 168 (1964).

33. Other tax provisions, having the same effect as $\$ 170(\mathrm{c})(4)$, were also involved, viz., $\S 642(\mathrm{c})$ (contributions by trust), $\$ \S 2055(\mathrm{a})(3)$ and $2106(\mathrm{a})(2)$ (iii) (cstate tax deductions), and $\$ 2522(\mathrm{a})(3)$ (gift tax deductions).

34. See Pitts v. Wisconsin Dep't of Revenue, 333 F. Supp. 662 (E.D. Wis. 1971). 
that "more is required to find a violation of the Constitution." The necessary additional element in $\S 501(c)(8)$, according to the court, is that it provides tax exemption "only to particular organizations with particular purposes, rather than across the board," thereby demonstrating governmental "approval of the organizations and hence their discriminatory practice." 35 The deduction granted to donors by $\$ 170(c)(4)$ was similarly found to specify "not only the [charitable, etc.] purposes which will satisfy the statute, but the vehicles through which those purposes may be achieved as well," thus marking "certain organizations as 'Government Approved' with the result that such organizations may solicit funds from the general public on the basis of that approval." 36

Both of these distinctions-between subsidies and income-defining provisions, and between particularized and "across the board" allowances-deserve close inspection.

\section{B. "Subsidies" and "Income-Defining" Provisions}

The distinction between tax provisions that serve as "subsidies" (or as "matching grants") and those that "are merely attempts to provide for an equitable measure of net income" or that "are simply part of the structure of an income tax based on ability to pay" has an extensive history in the literature of tax scholarship. ${ }^{37}$ The effort of tax scholars to distinguish "subsidies" from provisions that "measure net income" or that gear tax liability to "ability to pay" ultimately depends upon the acceptance of an "ideal" or "correct" income tax base that can serve as the standard for determining when existing law deviates from this Platonic ideal. For those tax commentators who believe that this

35. 338 F. Supp. 456.

36. Id. at 459 .

37. See Bittker, Accounting for Federal "Tax Subsidies" in the National Budget, 22 NAT'L TAX J. 244 (1969), and citations at pp. 244-46 thereof; Surrey and Hellmuth, The Tax Expenditure Budget-Response to Professor Bitther, id. at 528; Bitucr. The Tax Expenditure Budget-A Reply to Professors Surrey and Hellmuth, id. at 538; Surrey, Tax Incentives as a Device for Implementing Government Policy: $A$ Comparison with Direct Government Expenditures, 83 HARv. L. Rev. 705 (1970); Surrey, Federal Income Tax Reforms: The Varied Approaches Necessary to Replace Tax Expendilures with Direct Governmental Assistance, 84 HARv. L. REv. 352 (1970); Aaron, Inventory of Existing Tax Incentives-Federal, in TAX INstrTute of AMERICA, TAX INCENTIVes 39-49 (1969).

Although the theory that tax allowances are functionally equivalent to direct grants of governmental funds is popular with tax theorists, the Supreme Court in Walz v. Tax Commission, 397 US. 664 (1970) refused to treat them as identical, preferring instead to contrast "a direct money subsidy" with "the indirect cconomic benefit" of a tax exemption because, in its view, the latter is likely to involve less governmental surveillance and in any event is useful to the exempted institution only if it has property or income of its own: "The grant of a tax exemption is not sponsorship since the govern. ment does not transfer part of its revenue to churches but simply abstains from demanding that the church support the state." Id. at 675. 
distinction is fruitful, the standard is the Haig-Simons definition of income:

Personal income may be defined as the algebraic sum of (1) the market value of rights exercised in consumption and (2) the change in the value of the store of property rights between the beginning and end of the period in question. ${ }^{38}$

This is not the place for an examination, or even a catalogue, of the multitude of debatable judgments required in applying this definition to the myriad of transactions and activities that millions of taxpayers routinely engage in, which have led the Code to be characterized as "a dank, miasmic, myxomycetous sump." 30 We might simply note that no revenue act in the nation's history has complied with even the most elementary requirement of the Haig-Simons definition, i.e., that increases in the taxpayer's net worth (measured either annually or at the end of some other appropriate accounting period) be included in computing his income. Whatever may be said for the usefulness of this intellectual construct for other purposes, we question the validity of allowing constitutional obligations to hinge on it. Since the first step in identifying the "subsidies" that are burdened with constitutional obligations under McGlotten is to distinguish between "subsidies" and other tax allowances, the concept of an "ideal" income tax is central to the McGlotten rationale. But if the Fourteenth Amendment did not enact Herbert Spencer's principles of political economy, it is equally unlikely that it was intended to enact the Haig-Simons definition of income.

It is not even clear that the Haig-Simons definition is inconsistent with exempting nonprofit organizations (including fraternal orders) from an "ideal" income tax structure whose primary targets are private individuals and profit-oriented organizations. When auditing the books of nonprofit organizations, accountants do not prepare income statements that are comparable to those prepared for business organizations, and accounting treatises provide virtually no guidelines for the computation of the "income" of a nonprofit organization. For these reasons, Congress might well have thought that there was no satisfactory way to compute the income of nonprofit organizations, or that record-

38. H. Simons, Personal. Income Taxation at 61-62, 206 (1938).

39. Galvin, More on Boris Bitther and the Comprehensive Tax Base: The Practicalities of Tax Reform and the ABA's CSTR, in B. BitTkER, C. Galvin, R. Musciuve \& J. Pechman, A Compremensive Income Tax Base? 89 (1968), which reprints articles by these authors from 80 HARv. L. Rev. 925 (1967) and 81 HARv. L. REv. 44, 63, 1016, and 1032 (1968), with additional remarks. 
keeping for this purpose would ordinarily be unduly burdensome. Even if the income measurement obstacle is hurdled, Congress might have concluded that some types of nonprofit organizations ordinarily operate either at a loss or at too low a level of income to justify their inclusion in the taxing scheme. ${ }^{40}$ Congress might also have thought that nonprofit organizations have no "taxpaying capacity" as corporate bodies, reasoning that any income they may realize inures solely to the benefit of their members and beneficiaries. While this rationale would suggest allocating and taxing the organization's income to its members (as is done with partnership income), Congress might have thought this solution cumbersome, promising more administrative costs than revenue, either because of the large number of persons involved or because of difficulty in identifying the appropriate beneficiaries (who are not necessarily its members) to whom the organization's income should be imputed. Even the most enthusiastic devotees of the HaigSimons definition of income are prepared to accept departures from it that foster administrative convenience, avoid abrasive record-keeping rules, disregard de minimis calculations, and serve similar objectives. This tolerance for some play in the joints might well embrace the tax exemption accorded by $\S 501$ (c)(8) to fraternal orders, especially since they are subject to the normal corporate tax on any "unrelated business income" if they engage in ordinary business activities in competition with private enterprises. Whether for these reasons, or because its financial impact is difficult to estimate and likely to be trivial, $\S 501(c)(8)$ is not included, even by footnote, on any authoritative list of "tax subsidies" compiled by exponents of the Haig-Simons definition of income."1

Once the court in McGlotten determined (despite these alternative reasons for exempting nonprofit organizations from tax) that $\$ 501$ (c)(8) is a "subsidy," one might have expected that $\$ 501(c)(7)$, exempting social clubs (which, as stated earlier, were also under attack by the plaintiff if their membership rules were racially restrictive) would be rele-

40. Fraternal orders were exempted from tax by the Revenuc Act of 1913 along with many other nonprofit corporations; when the applicable provision was enlarged in 1916 to include several additional categories of nonprofit organizations, the House Ways and Means Committee commented:

It was deemed advisable to specifically extend the exemption to other corporations similar to those enumerated in the present law as exempt from tax in view of the fact that the experience of the Treasury Department has been that the securing of returns from them has been a source of expense and annoyance and has resulted in the collection of either no tax or an amount which is practically ncgligible .....

H.R. REP. No. 922, 64th Cong., Ist Sess. (1916), reprinted in 1939-1 Cus. BuLl. (1'art 2) $22,24$.

41. See lists contained in articles cited supra note 37 . 
gated to the same category. But the court concluded that the more limited tax exemption accorded to social clubs by $\S 501(\mathrm{c})(7)$ was not constitutionally vulnerable. Unlike fraternal orders, social clubs have been taxed since 1969 on their investment income, ${ }^{42}$ with the result that their tax exemption now embraces only the income derived from transactions with their members ("exempt function income"). The court held that this exemption is not the kind of "state action" that carries with it an obligation to provide equal protection:

$[T]$ he deduction for "exempt function income" does not operate to provide a grant of federal funds through the tax system. Rather, it is part and parcel of defining appropriate subjects of taxation. Congress has determined that in a situation where individuals have banded together to provide recreational facilities on a mutual basis, it would be conceptually erroneous to impose a tax on the organization as a separate entity. The funds exempted are received only from the members, and any "profit" which results from overcharging for the use of the facilities still belongs to the same members. No income of the sort usually taxed has been generated; the money has simply been shifted from one pocket to another, both within the same pair of pants. Thus the exclusion of membergenerated revenue reflects a determination that as to these funds, the organization does not operate as a separate entity. ${ }^{43}$

This rationale fails to acknowledge that transfers of money "from one pocket to another, both within the same pair of pants" are regularly taxed by the Internal Revenue Code. Sales by a one-man corporation to its sole shareholder (and vice versa), for example, are regularly taxed, as are distributions by the corporation to its shareholder. Sales and other transactions between husbands and wives, parent and subsidiary corporations, grantors and their trusts, and many other categories of related taxpayers also routinely generate "income of the sort usually taxed" by the Internal Revenue Code; indeed, the general rule is that a transaction is subject to tax unless it can fit within an explicit statutory exemption.

Moreover, a social club's member-generated income might be thought even less deserving of an exemption than income resulting from transactions between taxpayers with a common economic interest. The reason is that income generated from the facilities patronized by one group of members (and their guests) may well inure to the bene-

42. INT. REv. Cone $\$$ 512(a)(3), explained by S. REP. No. 91-552, 91st Cong., 1st Sess., reprinted in 1969-3 Cum. BuLl. 423, 469-71. But see note 53 infra.

43. 338 F. Supp. at 458. 
fit of a different group: the golfers may pay fees that subsidize the tennis players; inactive members may pay dues that subsidize those who use the club's facilities frequently; and so on. This economic gain, enjoyed by members who have no community of economic interest with those who "lose," might well be thought a more suitable target for taxation than the gain arising when one spouse sells property to another, or when a one-man corporation is dissolved and distributes its assets to its sole shareholder. Related taxpayers of this type, having a common economic interest, are more likely to be wearing "a single pair of pants" than the members of a social club. While countervailing reasons for exempting the member-generated income of social clubs can be offered, along the lines suggested by the court, it is hard to perceive a constitutional difference between exempting the membergenerated income of social clubs and exempting both this type of income and the passive investment income of fraternal orders.

This distinction between fraternal orders and social clubs becomes even more problematical when one notes that if MicGlotten had arisen before 1969, social clubs would have fallen within its reach because their passive investment income was then exempted in the same way that the investment income of fraternal orders is now exempted. Although social clubs no longer enjoy this tax concession, it undoubtedly was a source of funds that enabled some social clubs to purchase and furnish their clubhouses and to acquire income-producing endowments-to the continuing advantage of their current members. This would not justify a determination that all social clubs are indissolubly impressed with a public character, but it seems to invite-if the "subsidy" rationale of $M c$ Glotten is accepted-an assessment in each case of the current importance of these accumulations. Yet McGlotten has evidently cut off this possibility by its threshold conclusion that the only tax exemption currently enjoyed by social clubs is not a "subsidy" but an income-defining provision. Perhaps the McGlotten court would have been prepared to order a social club to admit members on a racially neutral basis if the exemption of its investment income from tax in past years enabled it to operate below cost today. ${ }^{44}$ If so, the consequences would be formidable: every revenue act since 1909 contained "subsidies" that, though repealed, would impose continuing constitutional obligations on any taxpayer who has not yet dissipated the benefits received in prior years.

A final point. The stress in this discussion on the income tax al-

44. See p. 60 supra. 
lowances accorded to fraternal orders and their benefactors should not obscure the fact that the McGlotten court also held that $\$ 2055(\mathrm{a})(3)$, $\S 2106(a)(2)($ iii), and $\S 2522(a)(3)$-permitting contributions to the charitable functions of fraternal orders to be deducted in computing the donor's federal estate and gift taxes-are unconstitutional if the fraternal order has a racially restrictive membership rule. The significance of applying the court's "subsidy" theory to estate and gift taxes is that tax commentators, so far, have not gone beyond the fed. eral income tax in distinguishing between provisions that serve as "subsidies" and those that define the taxable base or event. For other taxes, there are rudimentary formulas to separate the sheep from the goats, but none that commands the prestige of the Haig-Simons definition of income. If there is to be a constitutional dimension to exemptions, deductions, and other allowances in taxes imposed by the federal, state and local governments, therefore, the courts will have to proceed without much help from tax theorists.

\section{C. "Particularized" versus "Across the Board" Allowances}

One of the sources of the McGlotten court's distinction between "subsidies" and "income-defining" provisions contains a list of "tax expenditures" (a term that is conceptually interchangeable with "subsidies").45 An examination of this catalogue, which estimates aggregate "tax expenditures" of almost $\$ 47$ billion for the fiscal year 1969, quickly discloses that "subsidies" are as ubiquitous as fire and police protection. Virtually every individual taxpayer is the beneficiary of a "tax expenditure," since the term includes both the itemized personal deductions (e.g., interest, charitable contributions, medical expenses, and local taxes) and the optional standard deduction that is taken by those who do not itemize. Those who do not qualify for these subsidies, because they are too poor to file a federal income tax return, will find that the exemption of welfare payments, social security benefits, unemployment insurance and workmen's compensation is also a subsidy. As for corporations, they too have a rich diet of subsidies, ranging from the $\$ 25,000$ surtax exemption that is granted to every corporation or group of controlled corporations to dozens of more esoteric, but widely available, tax allowances.

The McGlotten decision seeks to avoid the conclusion that everyonc is subject to constitutional obligations ${ }^{48}$ by holding that some tax sub.

45. Surrey, supra note 37, 84 HARv. L. REv. at 356-57.

46. In rejecting this possibility, the McGlotten court is of course in agrecment with the commentators, who have struggled mightily either to impose limitations on the "statc 
sidies entail more governmental sponsorship than others. Discussing the tax exemption accorded to fraternal orders by $\$ 501(c)(8)$, the court says:

We think this exclusion, provided only to particular organizations with particular purposes, rather than across the board, is sufficient government involvement to invoke the Fifth Amendment. By providing differential treatment to only selected organizations, the Government has indicated approval of the organizations and hence their discriminatory practice, and aided that discrimination by the provision of federal tax benefits. ${ }^{47}$

It is not clear what the court meant by "differential treatment" in contrasting the exemption of "particular organizations with particular purposes" with an apparently permissible "across the board" exemption. If Congress repealed the federal income tax, no doubt this would be classed under McGlotten as "across the board" action, so that the benefit thereby conferred on fraternal orders would not constitute unconstitutional "aid" to those with racially restrictive membership rules. But if Congress taxed all business organizations while exempting all nonprofit ones, would the McGlotten theory treat this action as "differential treatment" of fraternal orders, and hence a forbidden federal aid to discrimination, or as an "across the board" exemption for all nonprofit organizations which incidentally, and without constitutional objection, inures to the benefit of discriminatory fraternal orders? If such an "across the board" distinction between profit-oriented and nonprofit organizations is constitutionally permissible under McGlotten, it would seem to follow that discriminatory fraternal orders can benefit from any exemption that submerges them in a sea of "comparable" organizations, even if it simultaneously separates them from "different" organizations.

This reasoning, indeed, is endorsed by the court in holding that the tax exemption enjoyed by social clubs under $\$ 501$ (c)(7) is not unconstitutional. After asserting that the exemption of a social club's member-generated income is not a "subsidy" (but is rather an incomedefining provision), the court went on to ask whether the exemption

action" doctrine in recognition of the fact that no one lives in a state of statelessness, or to replace it with some other formula. See the review of this "conceptual disaster area" by Black, "State Action," Equal Protection, and Califomia's Proposition 1f, 81 Harv. L. REv. 69 (1967), especially at 95-109; see also Mloose Lodge No. $107 \mathrm{v}$. Irvis, 407 US. 163,173 (1972), which points out that something more than receipt of "such necessities of life as electricity, water, and police and fire protection" is required to trigger application of the Equal Protection Clause.

47. 338 F. Supp. at 459 . 
constitutes a "mark of Government approval." 48 The answer, according to the court, is that no approval is manifested because $\S 501(\mathrm{c})(7)$

does not limit its coverage to particular activities; exemption is given to "clubs organized and operated exclusively for pleasure, recreation and other non-profitable purposes." 40

The court's determination that the exemption for social clubs is not limited to "particular activities" contrasts with its finding that the exemption for fraternal orders is "provided only to particular organizations with particular purposes." The basis for these contrasting findings is apparently that the inclusion of the phrase "other non-profitable purposes" in $\$ 501(\mathrm{c})(7)$-italicized by the court to stress the pointmakes the group of organizations covered by this provision broad enough to take social clubs out of the category of "particular organizations."

But the court could fairly have reached the same result for fraternal orders. They are not singled out by the Code for unique treatment, but are instead taxed in substantially the same manner as a number of other nonprofit organizations, including labor unions, agricultural organizations, business leagues, and chambers of commerce. ${ }^{50}$ These organizations are, in general, taxed more leniently than business corporations, ${ }^{51}$ and in this sense they benefit from "differential treatment"; but if they are viewed as a group, they share in an "across the board" exemption. Their exemptions, to be sure, appear in different paragraphs of the Code-though all are part of the same subsection-

48. Compare Walz v. Tax Commission of City of New York, 397 U.S. 664, 672 (1970), where the Supreme Court described the exemption of church property from state property taxes as "neither the advancement nor the inhibition of religion; ... neither sponsorship nor hostility . . . simply sparing the exercise of religion from the burden of property taxation levied on private profit institutions." It should perhaps be pointed out, how. ever, that Walz did not involve a problem of "state action." "State action" was clcarly present there, as it was in Everson v. Board of Education, 330 U.S. 1 (1947). "Stitc action," in short, is a necessary but not a sufficient condition to an "establishment of religion." The McGlotten decision, therefore, does not lead inexorably to the conclusion that tax deductions for religious contributions or tax exemptions for churches are invalid under the First Amendment.

49. 338 F. Supp. at 458 .

50. INT. REv. ConE $\S \S 501(c)(5)$ and (6).

51. But they may on occasion be taxed less favorably than business corporations, since their unrelated business income is taxed even if they incur losses in their in. vestment, related business, or other activities, while a business corporation can aggregatc its activities in computing income and hence is taxed only if it has an overall proflt. It is not clear, however, whether a nonprofit organization that loses its exempt status can deduct the expenses of its nonprofit activities from its business incomc. If it catn, McGlotten could have the paradoxical result of reducing the taxes of some scgregated fraternal orders. See Adirondack League Club v. Commissioner, 55 T.C. 796 (1971), aff'd per curiam, 458 F.2d 506 (2d Cir. 1972); United States v. Fort Worth Club, 348 F.2d 891 (5th Cir. 1965). 
but it cannot be that constitutional obligations hang on this accident of statutory draftsmanship.

The court concludes its discussion of the tax exemption granted to social clubs by observing that it does not constitute a mark of governmental approval because

Congress has simply chosen not to tax a particular type of revenue [the member-generated income of $\$ 501(c)(7)$ organizations] be. cause it is not within the scope sought to be taxed by the statute. ${ }^{52}$

But this statement is little more than a tautology. Moreover, by describing the exempt function income of social clubs as "a particular type" of income, the court virtually concedes, albeit unwittingly, the weakness of the alleged distinction, relied on elsewhere, between "particular" and "across the board" legislation. This concession emerges from the ultimate fact that both social clubs and fraternal orders have four major "particular types" of income: dues paid by their members, profits arising in transactions between them and their members, investment income, and income from unrelated business activities. Of these four types of income, the first two are exempt and the fourth is taxed, whether the recipient is a social club or a fraternal order; the third, however, is taxed to social clubs ${ }^{53}$ but not to fraternal orders. It is this single disparity that must support the court's distinction between "particular" and "across the board" tax allowances.

The concept of "differential treatment," then, is elusive, and the opinion in McGlotten does little to clarify its ambit. There are, to be sure, several efforts to buttress this rationale with references to governmental "approval" of fraternal orders and of their charitable functions. But "approval" of an organization by anyone-the government, the organization's members, or even its officers-does not necessarily imply approval of all its policies and practices, and the term "approval" is in any event a dubious characterization of the purpose and effect of $\$ 501(c)(8)$. High praise for charitable, religious, and educational organizations may be found in the meager legislative history of $\$ 501$ (c) (3), but the purpose of the exemptions found in the other paragraphs of $\S 501$ (c) is less clear. As suggested earlier, they may reflect a judg-

52. 338 F. Supp. at 458.

53. If set aside for charitable purposes, however, a social club's investment income is treated as "exempt function" income. See INT. REv. CoDE $\$ 170(\mathrm{a})(3)(\mathrm{B})(\mathrm{i})$. Since this part of the club's investment income is taxed neither to the club nor to the members, they enjoy a $\operatorname{tax}$ allowance that is substantially equivalent to the deduction that is granted by $\$ 170(c)(4)$ for charitable contributions to fraternal orders. Had this been brought to the court's attention, it might have refused to distinguish between segregated social clubs and segregated fraternal orders. 
ment that nonprofit organizations are unnatural targets for income taxation (unless they engage in unrelated businesses) or that their "income" is often difficult to compute, or that they so rarely operate at a profit that the potential revenue to be gained by taxing them is not worth the administrative costs.

At one point in its opinion, the court states that the Internal Revenue Code permits fraternal orders "to represent themselves as having the imprimatur of the Government," a remark evidently referring to the fact that such an organization can apply to the Internal Revenue Service for a ruling to the effect that it meets the requirements of $\S 170(c)(4)$. More explicitly, the court says:

A contribution, even for an approved purpose is deductible only if made to an organization of the type specified in $\$ 170$ and which has obtained a ruling or letter of determination from the Internal Revenue Service. Thus the government has marked certain organizations as "Government Approved" with the result that such organizations may solicit funds from the general public on the basis of that approval. ${ }^{54}$

In fact, however, while a ruling or determination letter is helpful in soliciting contributions (because it assures donors that their gifts will be deductible), it is not a prerequisite to deductibility, which can be established after the fact by evidence that the organization met the standards of $\S 170.55$ In any event, rulings and determination letters are not the peculiar privilege of nonprofit organizations; they are issued to taxpayers who are about to engage in almost every species of business and personal transaction if they want an advance assurance of its tax status for themselves or for other persons whose cooperation or participation they wish to encourage. ${ }^{66}$

Finally even if the distinction between "particularized" and "accross the board" tax allowances were far more clear, it would still be a puzzling criterion for separating tax allowances that are burdened with constitutional obligations from those that are not. Thus it lends the court to this conclusion:

54. 338 F. Supp. at 456.

55. In point of fact, there appear to be no published rulings under INT. REv. CoDE $\$ 170(c)(4)$, and the Treasury's Cumulative List of Exempt Organizations, which is regularly consulted by taxpayers who want assurance that their contributions will be de. ductible, includes $\$ 501(c)(3)$ (charitable, educational, etc.) organizations but not $\$ 501$ (c)(7) fraternal orders.

56. See B. Bittker \& L. Stone, Federal Income, Estate ANd Gift TAXation 927.82 and materials there cited (4th ed. 1972). 
We recognize that an additional class of deductions-such as accelerated depreciation for rehabilitated low income rental property [\$ $167(\mathrm{k})]$, or deductions for mortgage interest [\$ 163]- do act as "incentives" favoring certain types of activities. But unlike the charitable deductions [for contributions to fraternal orders] before us, these provisions go no further than simply indicating the activities hoped to be encouraged; they do not expressly choose fraternal organizations as a vehicle for that activity and do not allow such organizations to represent themselves as having the imprimatur of the Government. This seems to us a significant difference of degree in an area where no bright-line rule is possible. ${ }^{5 T}$

This distinction between the deductions allowed by $\$ 170$ for charitable contributions and those allowed by $\$ 167(k)$ for rehabilitating low-income rental housing has such surprising results as to cast doubt on its validity in deciding constitutional questions under the Equal Protection Clause. First, $\S 167(k)$ is more clearly in purpose, and probably in effect, an incentive to taxpayer behavior than the tax exemption for fraternal orders. Since the issue under Wilmington Parking Authority is the extent of governmental encouragement of the activity that discriminates, the fact that $\S 167(k)$ was clearly intended to increase the supply of a particular type of housing seems to suggest that it is at least as vulnerable as $\$ 170(c)(4)$, encouraging charitable contributions to fraternal orders, and more vulnerable than $\$ 501(c)(8)$, exempting the fraternal order's own income, for these provisions demonstrate no clear purpose to encourage the formation of such organizations. Second, though racial discrimination is odious whether practiced by landlords or by fraternal orders, it is hard to believe that discrimination by fraternal orders in the selection of members is more devastating than discrimination by landlords in selecting tenants; if one were forced to choose, the opposite would seem more likely. Third, when benefits are granted to any taxpayer who chooses to engage in the favored activity, racial discrimination should be even more objectionable, because it may be more widespread, than if the incentive program is confined to a limited class of taxpayers. The court's "chosen instrumentality" theory would apparently embrace such diverse taxpayers and organizations as insurance companies, mutual savings banks, real estate investment trusts, Subchapter $S$ corporations, farmers, qualified pension plans, and underdevelopedcountry corporations. What in the Equal Protection Clause could justify the imposition of constitutional obligations on this bizarre assort-

57. 338 F. Supp. at 457 . 
ment of bedfellows, but not on "normal" business corporations, partnerships, and proprietorships? Finally, $\S 167(k)$ is hedged about with a variety of restrictions that evidence a congressional concern with the details of the taxpayer's operations, its benefits being explicitly confined to rehabilitated housing that is

held for occupancy on a rental basis by families and individuals of low or moderate income, as determined by the Secretary [of the Treasury] or his delegate in a manner consistent with the policies of the Housing and Urban Development Act of 1968 pursuant to regulations prescribed under this subsection.

Faced by these statutory requirements, a builder who needs mortgage or equity money from either private or institutional investors is quite likely to ask for a ruling or determination letter of the kind that the court regards as a.governmental "imprimatur" when issued to a fraternal order, in order to assure the investors that his project meets the requirements of $\S 167(\mathrm{k})$. The court's suggestion that there is more significant governmental involvement with the operations of charitable organizations, therefore, is not convincing. The implication of extensive public supervision of charitable organizations, moreover, contrasts sharply with the views of both the critics and the defenders of the charitable contribution deduction. Its critics allege that there is inadequate government supervision over the organizations benefitting from this "subsidy" and over the purposes for which their funds are used, while its defenders argue that this very independence is a major virtue of the charitable deduction.

The very fact that the court must employ such ambiguous and unsatisfactory distinctions to avoid reaching the conclusion that every tax "subsidy" (and therefore every individual, business, and association) is burdened with constitutional obligations should indicate that something is wrong. Can constitutional rights really depend on refinements of such delicacy?

\section{Statutory Interpretation of the Internal Revenue Code}

In addition to its constitutional holding, the $M c$ Glotten court held that $\S 170(\mathrm{c})(4)$ of the Internal Revenue Code, when properly read, does not authorize donors to deduct contributions to support the charitable functions of segregated fraternal organizations. In support of this statutory ground for denying the deductions under attack the court said: 
there is a clearly indicated Congressional policy that the beneficiaries of federal largesse should not discriminate. WWe think this overriding public policy, even in the absence of our constitutional holding ... requires that the Code not be construed to allow the deduction of contributions to organizations which exclude nonwhites from membership. 58

As a canon of statutory construction, the principle that the Internal Revenue Code should not be interpreted to permit taxpayers to take deductions that would frustrate public policy has a long history, primarily with respect to the deductibility of fines, bribes, and illegal kickbacks paid in a business context. ${ }^{50}$ After a series of decisions holding that many expenditures of this type could not be deducted as business expenses, Congress in 1969 and 1971 enacted a set of statutory rules to govern this area. The Senate Finance Committee's 1969 report announced:

The [newly enacted] provision for the denial of the deduction for payments in these situations which are deemed to violate public policy is intended to be all inclusive. Public policy, in other circumstances, generally is not sufficiently clearly defined to justify the disallowance of deductions. ${ }^{60}$

While this statement might suggest that the new rules were to completely pre-empt the "frustration of public policy" doctrine, leaving no room for its use by the courts as a guide in construing any provisions of the Code, it might instead be read more narrowly to apply only to $\S 162$, relating to the deductibility of amounts claimed as business expenses.

Without explicit reference to this issue, a three-judge District Court employed the "frustration" doctrine in 1971 in Green v. Connally," holding that segregated private schools were not entitled to tax exemptions under the Internal Revenue Code and that their donors were not

58. 338 F. Supp. at 460 .

59. B. BITTKER \& L. STONE, supra note $\$ 6$, at 300.08 .

60. 1969-3 CuM. BuL.. 423, 597.

6I. 330 F. Supp. 1150 (D.D.C. 1971), affd sub nom. Coit v. Green, tot US. 997 (197I). An earlier installment is reported as Green v. Kennedy, 309 F. Supp. 1127 (D.D.C. 1970). See also Bob Jones University v. Connally, 341 F. Supp. 277 (D.S.C. 1971) (on appeal), temporarily enjoining the Treasury from revoking the exempt status of segregated religious educational institutions and from withdrawing rulings on the deductibility of contributions to them. The court stated that the purpose of the proposed Treasury action "is not to assess and collect taxes, but to compel [compliance] .. . with certain political or social guidelines with regard to the question of racial integration," id. at 284. See also Crenshaw County Private School Foundation v. Connally. 343 F. Supp. 495 (II.D. Ala. 1972) (INT. REv. CoDE $\$ 7421$ (a) requires dismissal of action to restrain Treasury from applying rulings described in Green v. Connally). 
entitled to deduct their gifts as charitable contributions. Two separate, though related, grounds were asserted for these holdings: first, that a well-defined public policy of desegregating education would otherwise be frustrated; second, that the term "charity" was used in the Internal Revenue Code in its common law meaning of a benevolent purpose or activity whose accomplishment is not contrary to public policy. Suggesting that racially restrictive educational institutions may no longer be regarded as "charitable" in this sense, ${ }^{02}$ the court went on to hold that they do not qualify for tax exemption under $\$ 501(\mathrm{c})(3)$ of the Code and that gifts to them are not "charitable contributions" qualifying for deduction under $\S 170 .^{63} \mathrm{~A}$ premise of this conclusion is that the term "educational" in "religious, charitable, scientific, testing for public safety, or educational purposes" is not used disjunctively in $\$ 501(\mathrm{c})(3)$, but rather refers to a species of "charitable" activity.

The McGlotten court relied on Green \%. Connally in holding that gifts supporting the charitable functions of segregated fraternal orders may not be deducted under $\S 170(\mathrm{c})(4) .{ }^{04}$ There are, however, two important differences between these cases. There is an abundance of evidence supporting the Green theory that segregated educational facilities contravene public policy; while public rather than private schools are the primary focus of this emphasis on racially open education, in Green the court was able to muster a number of earlier judicial decisions extending the same principle to private education. By contrast, the McGlotten court offered no comparable evidence that a fraternal order's racially restrictive membership rules violate public policy. In Moose Lodge, decided shortly after the McGlotten case, the Supreme Court did not mention any public policy objection to such rules in holding that a segregated fraternal order could retain a state liquor license, and a dissenting opinion by Mr. Justice Douglas (with whom Mr. Justice Marshall joined) explicitly asserted that fraternal orders are free to discriminate in their membership unless the state becomes involved in their activities:

My view of the First Amendment and the related guarantees of: the Bill of Rights is that they create a zone of privacy which precludes government from interfering with private clubs or groups. The associational rights which our system honors permit all white, all black, all brown, and all yellow clubs to be formed. They also permit all Catholic, all Jewish, or all agnostic clubs to

62. 330 F. Supp. at 1157 .

63. Id. at 1164 .

64. 338 F. Supp. at 460 . 
be established. Government may not tell a man or woman who his or her associates must be. The individual can be as selective as he desires. So the fact that the Moose Lodge allows only Caucasians to join or come as guests is constitutionally irrelevant, as is the decision of the Black Muslims to admit to their services only mem. bers of their race. ${ }^{65}$

In Douglas' view, freedom of association is the controlling value unless the fraternal order gets into "the public domain," and he dissented not because the Moose lodge held a liquor license, but because of two collateral aspects of the regulatory scheme. (These infirmities were an administrative requirement that every licensee comply with all of its own rules, including the discriminatory membership provision, and a state limit on the number of licenses, which gave the club a privileged status when public bars were closed.) ${ }^{60}$ The McGlotten court's "frustration" interpretation of $\$ 170(c)$ (4), however, was not based on the finding of state action "which underlies our constitutional determination" but was regarded as appropriate even if the fraternal order was a wholly private agency. A hint in McGlotten that a fraternal order's racially restrictive membership rules might be a "badge of servitude" within the meaning of the Thirteenth Amendment, offered to support the conclusion that tax allowances for such organizations would frustrate public policy, is also inconsistent with the majority opinion in Moose Lodge and the Douglas-Marshall dissent.

The only other evidence offered in McGlotten in support of its "frustration" theory is $\S 601$ of the Civil Rights Act of 1964, forbidding racial discrimination by recipients of federal financial assistance. Two more explicit provisions of recent civil rights legislation that suggest tolerance of, or indifference to, the membership restrictions of private clubs, however, were not mentioned. They are $\$ 201(e)$ of the $1964 \mathrm{Act}^{67}$ exempting private clubs from the requirement that places of public accommodation accept customers without regard to race; and $\$ 807$ of the Civil Rights Act of $1968,{ }^{08}$ creating an exception to the requirement that federally-financed housing must be rented without racial discrimination, by permitting private clubs to confine occupancy of non-commercial projects to their membership. In the absence of a widely accepted public policy against segregated

65. 407 U.S. at 179-80.

66. Id. at 181-83.

67. 42 U.S.C. $\$ 2000$ (a)(e) (1970).

68. 42 U.S.C. $\$ 3607$ (1970). 
fraternal orders, then, McGlotten's reliance on Green $v$. Connally, which was concerned exclusively with segregated educational facilities, is unpersuasive.

There is a second weakness in McGlotten's reliance on Green $v$. Connally. Since the schools in Green were exclusively for white pupils, the tax allowances under attack would inure to the benefit of a racially restricted group. In $M c$ Glotten, the charitable activities were to be administered by a segregated fraternal order, but it was not alleged that the benefits would be distributed on a racially restrictive basis; and if they were, the decision in Green would require any deductions claimed by the donors to be disallowed. McGlotten, however, forbids a deduction under $\$ 170$ (c)(4) even if the religious, charitable or educational activities sponsored by the fraternal order are open equally to all persons regardless of race. In support of this sweeping result, the court said in McGlotten:

Plaintiff alleges that he and others in his position are denied the opportunity to help determine the purposes to which the funds are devoted. Paternalism should not be confused with equality. ${ }^{00}$

But to the extent that the court relied on this point in holding that $\$ 170(\mathrm{c})(4)$ does not authorize contributions to be deducted if they are to be administered by a segregated organization, it offered no evidence supporting the idea that public policy would be frustrated by deductions in these circumstances. The fruits of philanthropy, as Judge Friendly has said in another context, "are often better than its roots."70 It is, of course, arguable that discrimination in administering charitable funds is so difficult to detect that an absolute prohibition on deductions would be a desirable prophylactic if the administering organization has a demonstrable propensity to discriminate in any of its functions, or that a segregated organization should not be allowed to harvest the favorable publicity produced by a non-discriminatory, tax-deductible program of charitable activity. But the $M c$ Glotten court suggested neither rationale in concluding that deductions are not authorized by $\S 170(\mathrm{c})(4)$ and, however suitable these safeguards might be as a basis for legislative action, there is no evidence that public policy would be frustrated by failing to embody them in $\S 170(\mathrm{c})(4)$.

In this connection, it should be noted that social clubs and other

69. 338 F. Supp. at 456, n.38.

70. Quoted in Green v. Connally, 330 F. Supp. at 1162, from Friendly, The Dartmouth College Case and the Public-Private Penumbra, 12 Texas L.Q. (2d Supp.) 141, 171 (1969). 
organizations that cannot act as recipients of deductible charitable contributions can create separate funds or affiliates for this purpose. ${ }^{71}$ If the fund or affiliate is organized and operated exclusively for charitable purposes, contributions to it can be deducted by the donors. ${ }^{72}$ Having held that public policy would be frustrated if donors were permitted to deduct contributions to the charitable functions of a segregated fraternal order under $\$ 170(c)(4)$, the McGlollen court might extend this holding to donors contributing to any charitable organization that is organized or sponsored by a segregated group, but this question was not explored in the opinion. If the court refused to so extend its holding, a distinction without a discernible difference would be created between a $\$ 170(c)(4)$ gift to a segregated fraternal order and a $\$ 170(c)(2)$ gift to its charitable affiliate or to the affiliate of some other type of segregated nonprofit organization.

\section{Violation of $\S 601$ of the Civil Rights Act of 1964}

After holding that it is unconstitutional to accord tax exemption to fraternal orders with racially discriminatory membership rules, and that the deduction of contributions supporting the charitable functions of such groups is both unconstitutional and unauthorized by the Internal Revenue Code, the McGlotten court went on to drive a final nail into the coffin by holding that both of these tax allowances constitute "federal financial assistance" in violation of $\$ 601$ of the Civil Rights Act of $1964 .^{73}$ Section 601 provides:

No person in the United States shall, on the ground of race, color, or national origin, be excluded from participation in, be denied the benefits of, or be subjected to discrimination under any program or activity receiving Federal financial assistance.

71. See Rev. Rul. 54-243, 1954-1 CuM. Bur. 92. See also Rev. Rul. 58.293, 1958-1 Cus. Burl. 146 (quasi-public library maintaincd by bar association that was exempt as a business league).

72. See also note 53 supra.

73. 42 U.S.C. \$2000d et seq. (1970).

The issues to be decided in McGlolten might be reordered in the following manner: (a) Are the tax benefits attacked by the plaintiff authorizcd by the Internal Revenue Code when claimed by a segregated organization or by donors to it? (b) If they are, do they violate $\S 601$ of the Civil Rights Act of 1964? (c) If not, are they unconstitutional? On holding that deductions under INT. REv. CODE $\$ 1 \% 0\langle c)(4)$ would frustmite public policy if the donee fraternal order is racially segregated, the court need not hase decided either issues (b) and (c). Since the plaintiff did not allege that the fratemal order's own tax exemption violated public policy, issue (b) was neecsarily reached, but on deciding that the exemption was condemned by $\$ 601$, the court did not have to decide issue (c). As to the tax exemption of segregated social clubs, the court implicitly agreed that it could be allowed without frustrating public policy, thus deciding issue (a) without discussion; and the determination that it did not constitute a "subsidy" settled both issues (b) and (c). 
"Federal financial assistance" is defined by $\S 602$ of the 1964 Act as "assistance to any program or activity, by way of grant, loan, or contract other than a contract of insurance or guaranty."

Having previously concluded that the charitable contribution deduction and the tax exemption granted to fraternal orders by the Internal Revenue Code are "subsidies" and hence are substantially the same as federal grants, the court held that they constitute "financial assistance" within the meaning of $\S 602$. The tax exemption granted to social clubs, however, was held to be outside the reach of $\$ 602$, because "limited . . . to member-generated funds and available regardless of the nature of the activity of the particular club." "4.4 In further explanation of this distinction between exempting social clubs and exempting fraternal orders, the court said that the latter exemption "cannot be explained simply as a matter of pure tix policy." ${ }^{\prime}$ "The point, evidently, is that a provision that "defines income" in pursuance of "pure tax policy" is not a subsidy, and hence does not constitute "federal financial assistance," while a Code pro. vision that is not required by (or that conflicts with) commonly accepted definitions of income is a subsidy. In substance, the court's reasoning fastens the Haig-Simons definition of income, or some undescribed variation of it, on $\S 602$.

When discussing the constitutional obligations of persons who enjoy tax allowances, the court drew back, as we have seen, from the theory that all tax "subsidies" (or "incentives") impose constitutional duties on their recipients. ${ }^{70}$ Instead, the court held that allowances granted to "particular" types of taxpayers and serving to manifest governmental "approval" are impressed with constitutional obligations, but that other tax "subsidies" are not. Although the matter is not free from doubt, the court may have intended to carry this distinction over from the constitutional area and to read it into the term "federal financial assistance." If so, the constitutional results described earlier in this article would be duplicated under $\S 601$ of the 1964 Act. Thus, mutual savings banks, real estate investment trusts, insurance companies, qualified pension plans, and a commune of other strange bedfellows would be subject to $\$ 601$, but "ordinary" business corporations, individual proprietors, and partnerships would be exempt unless they receive a "particularized" subsidy for engaging in a "particular" type of activity.

What these "particularized" subsidies are (other than the two con-

74. 338 F. Supp. at 462.

75. Id.

76. See pp. 68-70 supra. 
demned in the McGlotten case), however, is unclear, especially since the court said in its discussion of the constitutional issue that this category does not include a provision that might otherwise have been thought to be the quintessence of "particularity," viz., $\$ 167(k)$, which permits taxpayers engaged in the rehabilitation of low-income rental housing (under regulations consistent with the policies of the Housing and Urban Development Act of 1968 and mceting several other requirements) to depreciate investments faster than is normal as well as to disregard their salvage value. Yet if the court had been required to decide whether a program of direct federal subsidies for rehabilitating low-income housing was "federal financial assistance" within the meaning of $\$ 602$, it would surely have responded in the affirmative. Nothing in either the language or purpose of $\$ \$ 601-605$ suggests a distinction between programs providing financial assistance on a broad scale and those with a more particular clientele. This supports that if the McGlotten court were right in holding that any "tax subsidies" constitute "federal financial assistance" within the meaning of $\$ 602$, all tax subsidies, not merely some, would be covered.

If the court's "particular vs. general" distinction is abandoned, however, $\$ 601$ applies to all taxpayers who enjoy federal tax subsidies, i.e., to virtually everyone. The much-debated exemption of "MIrs. Murphy's boarding house" from Title II of the Act, "7 for example, would be nullified if she used a corporate shell to conduct her business or claimed an investment credit on purchasing a new stove. Even the exemption of contracts of insurance and guaranty from $\S 602$ itself would be simultaneously nullified by the fact that the recipients almost always operate in corporate form, and hence enjoy the $\$ 25,000$ surtax exemption "subsidy." Thus, the conclusion that "tax subsidies" constitute "federal financial assistance" leads to surprising results under $\$ \S 601-605$ whether one applies or rejects the McGlotten theory that tax subsidies can be divided into two categories, particular and general.

Whether broadly or narrowly defined, tax subsidies are also hard to fit into the administrative scheme established by $\$ 602$ and $\$ 603$ to enforce $\$ 601$ 's prohibition on discrimination. Section 602 directs every federal department empowered to extend financial assistance to issue rules and regulations (which are to become effective only on approval

77. See 42 U.S.C. $\$ 2000 \mathrm{a}(\mathrm{b})(1)(1970)$, relating to public accommodations, which exempts "an establishment located within a building which contains not more than five rooms for rent or hire and which is actually occupied by the proprietor of such establishment as his residence" from the obligation to serve all comers without discrimination or segregation on the ground of race, color, religion, or national origin. See Hearings Before Subcommittee No. 5 of the House Comm. on the Judiciary, 88th Cong., Ist Sess., ser. no. 4, pt. 2, at 1386 (1963). 
by the President) consistent with achievement of the statutory objectives, and to enforce compliance by terminating, or refusing to grant or continue, assistance. But this action is to be taken only after the agency has advised the recipient of his failure to comply, has determined that compliance cannot be secured by voluntary means, and has made "an express finding on the record" after granting the recipient an opportunity. for a hearing on his alleged noncompliance. The head of the agency is then required to file a "full written report of the circumstances and the grounds for [its] action" with the appropriate committees of Congress, the proposed action becoming effective only 30 days after the filing of this report. This procedure is suited to the prohibition of discrimination in programs that entail applications for federal financial assistance, enabling the federal agency to impose requirements, to police them while the benefits are being received, to withhold payments when noncompliance is suspected, and to bar the recipient from further participation in the program if noncompliance is established. It is less suitable for supervising the behavior of taxpayers whose only nexus with the responsible agency is the filing of an annual tax return, which often does not even disclose that the taxpayer has taken advantage of a "tax subsidy" (because the subsidy's effect is-quite properly-buried in a computation of which only the final result is carried to the return). The plaintiff in McGlotten asked the court to order the Treasury to issue regulations under $\$ 602$, but it is difficult to envision the proper relationship between the procedure prescribed by $\S 602$ (administrative notice, efforts to achieve voluntary compliance, hearings, a report to Congress, and termination or refusal to grant or continue the financial assistance) and the court's determination in McGlotten that the disputed tax allowances are unconstitutional. ${ }^{78}$

On the question of congressional intent to treat "tax subsidies" as "federal financial assistance," the court said:

Nothing in the massive legislative history of the 1964 Civil Rights Act sheds any light on whether assistance provided through the tax system was intended to be treated differently than assistance pro. vided directly. ${ }^{79}$

78. In Green v. Connally, 330 F. Supp. 1150 (D.D.C. 1971), aff'd mem. sub nom., 414 U.S. 997 (1971), the court established a detailed program for assuring compliance with its decision, but did not order the Treasury to isstic regulations under $\$ 602$. Under $M c G l o t t e n$, the Treasury will have to find a way to separate tax allowances that come within $\$ 602$ from those that are beyond its reach, since a necessary implication of the decision is that $\S 602$ regulations are required for all tax allowances within its purvicw, not merely for those before the court.

79. 338 F. Supp. at 461 . 
There is, however, evidence that if "tax subsidies" were embraced by the statutory language, the legislators were unaware of that fact. Thus, when the House Judiciary Committtee reported the bill that became the Civil Rights Act of 1964 (with no mention in the committee report of the possibility that tax allowances constituted "federal financial assistance"), there were a number of separate and dissenting statements by committee members that clearly assumed that "federal financial assistance" referred to grants of funds and loans by federal agencies. One member, for example, argued that the "objectives of nondiscrimination with respect to Federal financial assistance programs can be achieved in a much simpler and more workable way" by requiring "recipients of federal financial assistance, as a condition to receiving the grant or loan, [to] enter into an enforceable undertaking against discrimination in the administration of the program," to be enforced by legal remedies "for the violation of a contract." 80 This procedure, suggested by a Congressman who supported the bill as reported, could hardly have been proposed by someone who thought that tax subsidies were included in the term "Federal financial assistance." Opponents of the legislation, in their minority report and statements, objected to it on almost every conceivable ground, going far afield for ammunition; yet they did not even suggest that tax subsidies-probably the most ubiquitous of all federal programs-could be the foundation of federal action under $\$ \$ 601-605$. Conjuring up a reign of terror for farmers, homeowners, banks, labor unions, the press, veterans, teachers, and others, they listed dozens of federal benefits that might be withheld but conspicuously failed to mention tax "subsidies." One minority statement, for example, listed 65 federal programs that would be affected; ${ }^{81}$ there would have been little need to reach out for programs aiding Cuban refugees, the blind, teachers of mentally retarded children, and librarians if dozens of federal tax subsidies of much broader import could have been plausibly included in what was intended as a comprehensive parade of horribles.

Similarly, a list of covered programs prepared for Congressman Celler by the Deputy Attorney General made no mention of tax allowances, though it embraced such minor items as payments to three counties in Minnesota from the national forest fund, expenditures to control outdoor advertising, payments to the National Board for Promo-

80. Additional Views of Hon. George Meader, H.R. Rer. No. 914, 88th Cong., 2d Sess. (1963), reprinted in 2 U.S. CODE \& ADMus. News 2391, 2425 (1961).

81. Separate Minority Views of Hon. Richard H. Poff and Hon. William Cramer, id. at $2471-73$. 
tion of Rifle Practice, payments under the Migratory Bird Conservation Act, and grants for the drainage of certain anthracite mines. Moreover, the letter of transmittal expressed the view that grants to individuals do not constitute "assistance to any program or activity" within the meaning of $\S 602 .{ }^{82}$ The congressional debate on Title VI ( $\$$ 601-603) also supports the conclusion that the title was concerned with programs entailing money expenditures rather than tax allowances. Thus, Congressman Powell pointed out that Title VI was a generalized version of the so-called Powell Amendment, which he had offered as a rider to a number of appropriations bills:

Title VI would avoid the recurrence of acrimonious debate in the Congress as to discrimination in discussing individual Federal aid programs. ... The argument that is customarily made is that if the provision [i.e., the Powell Amendment] prevailed, the Senate might become involved in prolonged or protracted debate, or even a filibuster, and the result might be no legislation whatever. ${ }^{83}$

Similarly, Senator Pastore argued that Title VI would expedite the legislative process:

It is to avoid such a situation that Title VI would constitute as permanent policy of the U.S. Government the principle that discrimination will not be tolerated. This would eliminate all the confusion and discussion that arises every time a grant bill comes before the Senate. ${ }^{84}$

The first official public suggestion that Title VI's jurisdiction might include not only the kind of programs listed by the Deputy Attorney General in his letter to Congressman Celler, but also tax allowances, was made in a 1967 report on southern school desegregation by the U.S. Commission on Civil Rights. Describing the growth of private southern segregated schools, the Commission made this recommendation:

The Secretary of the Treasury should request an opinion of the Attorney General as to whether Title VI of the Civil Rights Act of 1964 or the Internal Revenue Code authorizes or requires the

82. Hearings on H.R. 7152 as amended by House Comm. on the Judiciary, 88th Cong., 2d Sess., pt. IV, ser. 4, at 2773, 2776-78 (1964).

83. 110 Cong. Rec., Part 2, 2465 (1963).

84. Id. at 7061 [emphasis added]. For a detailed examination of Title VI's cvolution, scope, and effect, see Comment: Title VI of the Civil Rights Act of 1964-Implementation and Impact, 36 Geo. WASH. L. REV. 824 (1968), which contains no cvidence that the term "federal financial assistance" was intended to embrace tax allowances. For an of. ficial exposition of the scope of Title VI, see U.S. Commission ON Civil Ricirts, FEDERAL Givil Rights ENForcement EFForT 550-764 (1970). 
Internal Revenue Service to withhold tax benefits presently being afforded by the Service to racially segregated private schools, or whether congressional action is necessary to assure that such benefits are withheld. The Attorney General should consider whether, because of such benefits, the Federal Government is so significantly involved in private school segregation as to justify legal action to enjoin the continued operation on a discriminatory basis of schools receiving such benefits. If the Attorney Genernl determines that present legal authority is inadequate either to withhold tax benefits or to permit the institution of litigation, he should recommend appropriate legislation to the President. ${ }^{85}$

The Commission coupled this carefully guarded suggestion with a disclaimer of any intent to extend Title VI to social clubs and fraternal orders, explicitly citing $\S 501(c)(7)$ and $(\delta)$ as provisions that would be beyond the ambit of Title VI. In drawing this distinction between segregated schools and segregated fraternal orders and social clubs, the Commission asserted that the rights of privacy and of free association might have to be preferred "over the claim of equality, even if the discrimination is based on race." 80 The Civil Rights Division of the Justice Department subsequently adopted the position that was eventually endorsed by Green $v$. Connally (viz., that segregated schools are not organized and operated "for charitable or educational purposes" within the meaning of the Internal Revenue Code) in an unpublished opinion that cited Title VI as evidence of a national policy against segregated education. Apparently the Division did not assert, however, that tax allowances constitute federal financial assistance requiring Treasury action under Title VI. ${ }^{\mathrm{si}}$ If it had adopted this construction of Title VI, and if it had won the approval of the Attorney General, presumably the government should not have offered a defense on the merits in the McGlotten case.

Thus, neither the legislative history of Title VI nor the understanding of the agencies with major responsibility for its administration provide any solid support for treating federal tax allowances as "federal financial assistance" within the meaning of $§ 602$.

85. U.S. Commission on Civil Rigits Rerort, Southers School Destgrkgation, 196067 , at $99(1967)$.

86. Id. at 160. The constitutional flavor of this comment implies that Congress did not have the power to bring these exemptions within Title VI. If this were the only reason for excluding social clubs and fraternal orders from Title VI, one might deduce that all tax allowances were covered except those that are constitutionally immune. The Commission, however, was obviously preoccupied with the private school problem, and made no effort to present a developed theory' of Title VI's coicrage.

87. The Division's memorandum is summarized in U.S. Comsısssos ox Civit RIGirts, Federal Civil RIGHTS ENForcesiest EFFORT 563 (1970), which also describes the action taken by the Internal Revenue Service. 


\section{Conclusion}

Viewed in the abstract, fraternal orders and social clubs with racially restrictive membership rules are not admirable institutions. The same can be said of groups with restrictions based on religion, ethnic or national origin, sex, and political affiliation; these tests can also produce "suspect classifications," and they are as unconstitutional as race when used to determine who may serve on a jury, attend a public school, or be served in a place of public accommodation. But when, moving from the abstract to the particular, one examines the objectives and activities of particular fraternal orders and social clubs, membership restrictions based on any of these characteristics no longer seem automatically to be offensive. The correct adjective, rather, may be ludicrous, harmless, innocent, anachronistic, defensive, evanescent, inconsequential, functional, embattled, or praiseworthy. Even when the restrictions are invidious, a governmental program to discover and eradicate them necessarily imposes social costs; a society that tries to punish every instance of man's inhumanity to man may lose its humanity while crusading against the enemy. The "right of free association" and "the right of privacy" that have been vindicated in a series of recent Supreme Court decisions are labels recognizing the social value of membership organizations and the dangers inherent in governmental controls. ${ }^{88}$ Like free speech and the privilege against self-incrimination, however, the rights of free association and privacy cannot be reserved for the noblest among us.

If full sway is given to the $M c$ Glotten theory that tax allowances are equivalent to direct grants of public funds and hence impose constitutional obligations on the recipient, no one will be immune. As we have pointed out, the Internal Revenue Code is a pudding with plums for everyone. In theory, the "tax subsidy" theory does not constrict the right of free association or the right to privacy, because the tax allowances can be renounced by the recipient or eliminated by Congress. But the former remedy, by distinguishing among associations by reference to their ideologies, would make some pay a high price for their enjoyment of the rights in question. On the other hand, the congressional remedy of repeal, resting on the dubious premise that there is a "constitutionally neutral" definition of taxable income, would be costly to all associations.

88. See NAACP v. Alabama, 357 U.S. 449 (1948); Gibson v. Florida Investigation Com. mittee, 372 U.S. 539 (1963); Griswold v. Connecticut, 381 U.S. 479, 482.84 (1965); supra note 65 . 
The McGlotten court sought to minimize these consequences by picking and choosing among tax subsidies. But its distinctions, in our opinion, are unworkable and, as adumbrated by the court, impose or withhold constitutional obligations in a puzzling fashion. The "state action" doctrine as applied in Burton v. Wilmington Parking Authority is imprecise, but it permits values to be weighed and judgments to be made, so that a cluster of rooms in a college dormitory can be distinguished from a restaurant in a public facility, a bowling league from a bar association, and a radio repair shop from a $T V$ broadcasting network. ${ }^{89}$ Because application of the Equal Protection Clause is "peculiarly dependent for its invocation upon appropriate facts," the Court warned against automatically extending the conclusions "drawn from the facts and circumstances of this record" to "every state leasing agreement." willing to distinguish among tenants in the very same building, and that the obligation to serve all potential customers that was imposed on the restaurant in the case before the court would not necessarily have been imposed on a religious organization, ethnic society, labor union, fraternal order, or social club renting office space in the building. Wilmington Parking Authority thus enables the lower courts to focus on facts and circumstances that matter. By contrast, the tax subsidy theory-whether in an unadulterated form or as watered down by McGlotten-turns on technical niceties of tax law that are unrelated to the impact of the organization's behavior on the persons excluded by its membership rules or other restrictive practices. It would, therefore, be a mistake to use this theory to "constitutionalize" the Internal Revenue Code.

89. See Black, supra note 46. See also Brown, Emerson, Falk \& Freedman, The Equal Rights Amendment: $A$ Constitutional Basis for Equal Rights for Women, 80 Yale L.J. 871, 905-07 (1971).

90. 365 U.S. at 725-26. 


\section{The Yale Law Journal}

Volume 82, Number 1, November 1972

Richard Blumenthal

Editor-in-Chief
Peter T. Grossi, Jr.

Executive Editor
Curt Hessler

ROBERT B. Reich

Charles L. Woltmann Article Editors
Ralph R. ARditi

Michael J. BeAN

Michael J. Churgin

Michael M. Conway

Christopher C. Curtis

Kathleen M. DoggetT

Peter H. Ehrenberg

Robert W. Fisher

DONALD J. FRIEDMaN

Nancy C. Garrison

FREDERICK GOLDBERG, JR.
ROGER W. FONSECA

Charles A. Goldmark

HenRy B. HansmanN

DANIEL J. KORNSTEIN Jay E. Powell

Note \& Comment Editors

Steven R. Gross

Frederick Heller, JR.

Peter M. Hoffman

Randall K.C. KaU

Eugene A. Ludwig

JAMES T. MALYSIAK

ROBERT B. MaNN

S. HARDWICKE MAYS, JR.

NeIL H. O'DonNell

RusSELl K. OsGoOD
ROUERT E. GipsoN Managing Editor

NANCY Y. Bekavac

Book Revietus Editor

Business Secretaries M. Olive Butterfield, Pamela Willmott

\section{Student Contributors to This Issue}

Frederick T. Goldberg, Equalization of Municipal Services: The Economics of Serrano and Shaw

Robert F. Nagel, Legislative Purpose, Rationality and Equal Protection

Jeffrey I. Zuckerman, "Preliminary Preliminary" Relief Against Anticompetitive Mergers

Neil H. O'Donnell, Standards for Exclusion in Immunity Cases after Kastigar and Zicarelli 